\title{
ANALISIS KEPENTINGAN INDONESIA DALAM MERATIFIKASI PIAGAM ASEAN (ASEAN CHARTER)
}

\author{
Muh Kadarisman \\ Universitas Kristen Indonesia \\ Jl. Mayjen Sutoyo, Jakarta \\ kadarisman.bkn@gmail.com
}

\begin{abstract}
The research question is what is Indonesia's interest in ratifying ASEAN Charter? The research purpose is to understand and analyse factors that become beackground of the Indonesian government to ratify ASEAN Charter. Method: analytical descriptive, making description in systematic, factual and acurate way on facts, characteristics and relation among phenomenon that have been researched to get complete information about the important of Indonesian government in ratifiying ASEAN Charter. Technique of data collection is by library research. Data is analysed qualitatively by connecting factors and phenomenon related to the research, to have result and answer which compatible with the research purpose. The result of research are firstly the interest of Indonesia to ratify ASEAN Charter is closely connected with the development of relations among nations in the world, which need to make adjustments toward its foreign policies to guarantee Indonesia national interest based on strong legality. Secondly, the area cooperation in the initial formation of ASEAN is still functional which are in the field of economics, social, knowledge and technology. The present development of international politics is increasing the awareness of members of ASEAN countries to conduct collective cooperation to encourage the process of regional integration either in economics, politics or sociocultural and to reduce all obstacles in creating regional integration and stability so that ASEAN cooperation becomes more solid.
\end{abstract}

Key Words: National Interest, ASEAN Integration

Abstrak: Permasalahan penelitian: Apa kepentingan Indonesia dalam meratifikasi Piagam ASEAN? Tujuan penelitian: Untuk memahami dan menganalisis hal-hal yang melatarbelakangi Pemerintah Indonesia meratifikasi Piagam ASEAN. Metode penelitian: menggunakan deskriptif analitis, yaitu membuat suatu gambaran secara sistematis, faktual, dan akurat mengenai fakta-fakta, sifat-sifat serta hubungan antar fenomena yang diteliti, sehingga mendapatkan informasi menyeluruh tentang pentingnya pemerintah Indonesia meratifikasi Piagam ASEAN. Teknik pengumpulan data, dengan studi kepustakaan. Analisis data, menggunakan analisis kualitatif yaitu menghubungkan faktor-faktor dan gejala-gejala yang terkait dengan penelitian, sehingga didapatkan hasil atau jawaban sesuai dengan tujuan penelitian. Hasil penelitian ini adalah pertama, kepentingan Indonesia dalam meratifikasi Piagam ASEAN, erat kaitannya dengan semakin berkembangnya hubungan antar bangsa-bangsa di dunia, yang membutuhkan penyesuaian-penyesuaian terhadap kebijakan politik luar negeri demi terjaminnya kepentingan nasional Indonesia atas dasar hukum yang kuat (legal personality). Kedua,lingkup kerja sama awal terbentuknya ASEAN adalah masih bersifat fungsional, yaitu di bidang ekonomi, sosial, ilmu pengetahuan dan teknologi. Perkembangan politik internasional kini menumbuhkan kesadaran negara Anggota ASEAN guna melakukan kerja sama kolektif dalam mendorong proses integrasi regional lebih luas baik di bidang ekonomi, politik maupun sosial budaya, serta menghilangkan segala hambatan guna terciptanya integrasi dan stabilitas regional, sehingga menjadikan kerja sama ASEAN semakin solid.

Kata Kunci: Kepentingan Nasional, Integrasi ASEAN

\section{Pendahuluan}

Dalam kurun waktu 43 tahun, akhirnya The Association of South East Asian Nations (ASEAN) memiliki piagam yaitu "ASEAN Charter" yang dihasilkan pada pertemuan puncak 
Konferensi Tingkat Tinggi (KTT) ke-13 di Singapura pada tanggal 20 November 2007. Piagam tersebut ditandatangani oleh para pemimpin negara dari ke sepuluh kepala negara anggotanya (Indonesia, Malaysia, Singapura, Filipina, Thailand, Brunai Darussalam, Kamboja, Laos, Myanmar, dan Vietnam). Salah satu harapan dari piagam ini dapat mentransformasikan ASEAN dari sebuah asosiasi, menjadi suatu organisasi yang memiliki legal personality serta mekanisme dan struktur organisasi yang lebih jelas, dengan kata lain organisasi yang memiliki perspektif hukum. Selama ini ASEAN hanya menjadi organisasi regional di kawasan Asia. Dengan penandatanganan piagam tersebut, organisasi ini dapat mewujudkan visinya untuk menciptakan komunitas ASEAN yang mampu dipandang dunia internasional.

Walaupun dalam rumah tangga masing-masing anggotanya masih terdapat permasalahan yang belum terselesaikan, salah satunya yaitu permasalahan Hak Asasi Manusia (HAM), seperti negara Indonesia terkait kasus tragedi Semanggi 1 dan 2, dan tragedi Dili. Selanjutnya di Myanmar terkait kasus Aung San Syuu Kyi (pemimpin kelompok oposisi). Begitu pula, akhirakhir ini terjadi demonstrasi besar-besaran di Malaysia yang menuntut pelaksaan pemilu yang lebih demokratis serta objektif, dan beberapa kasus lainnya yang terjadi di hampir setiap negara anggota ASEAN. Penegakan prinsip-prinsip demokrasi dan HAM adalah misi yang akan dibenahi secara bertahap. Selain itu, permasalahan ekonomi juga menjadi bahan yang dibahas, setelah penandatanganan tiga deklarasi kerja sama yaitu cetak biru ASEAN Economic Community (AEC), ASEAN Declaration on the 13th Session of the Conference on Climate Change (UNFCCC), dan the 3rd Conference of parties Serving as the Meeting of the Parties (CMP) to the Kyoto Protocol, serta permasalahan sosial budaya. Perkembangan politik internasional yang terjadi kini, telah menumbuhkan kesadaran negara-negara ASEAN untuk melakukan kerja sama secara kolektif dalam mendorong proses integrasi regional yang lebih luas baik di bidang politik, ekonomi, maupun sosial budaya.

Dengan kata lain, terdapat keinginan dari negara-negara di kawasan Asia Tenggara untuk menghilangkan berbagai hambatan, guna menciptakan integrasi dan stabilisasi kawasan negaranegara di Asia Tenggara. Disadari, bahwa selama ini ASEAN belum dapat mewujudkan suatu identitas kolektif yang dapat memberikan kemajuan antar sesama negara anggota. Prinsip utama didirikannya ASEAN antara lain adalah persamaan kedudukan dalam keanggotaan, tanpa mengurangi kedaulatan ke dalam maupun ke luar. Musyawarah, kepentingan bersama, dan saling membantu dengan semangat ASEAN merupakan ciri kerja sama ini. Oleh karena itu, ketika telah terbentuk Piagam ASEAN, maka organisasi yang telah bersatu tersebut akan lebih menyatu lagi sebab dalam setiap perjanjian atau perikatan dan kesepakatan yang dibuat akan mengikat sertiap anggotanya. Keberhasilan ASEAN menciptakan stabilitas intra-kawasan di Asia Tenggara, juga 
diikuti oleh kemampuan ASEAN untuk menjadi pendorong proses integrasi kawasan yang lebih luas. Secara eksternal, ASEAN menghadapi tantangan dunia luar yang bergerak begitu cepat dengan munculnya kekuatan-kekuatan baru di Asia Pasifik seperti Cina dan India, menuntut negara-negara di ASEAN untuk melakukan kerja sama yang lebih solid dan menyeluruh.

Faktor lain yang mendorong proses transformasi ASEAN adalah adanya globalisasi. Kuatnya pengaruh globalisasi, mengakibatkan timbulnya nilai-nilai baru yang harus dihadapi oleh setiap negara-negara di dunia. Kondisi hubungan internasional yang didominasi oleh kepentingan dan aktivitas ekonomi yang menganut sistem ekonomi pasar, mengakibatkan terjadinya hubungan yang tidak seimbang antara negara maju khususnya negara-negara industri dengan negara-negara berkembang. Dalam hal ini, negara-negara industri maju menikmati keuntungan dengan berusaha menguasai pasar. Hal inilah yang mendorong proses transformasi ASEAN dari suatu organisasi yang agak longgar menjadi sebuah komunitas yang saling mengikat antar sesama negara anggota. Cita-cita ASEAN untuk membentuk satu komunitas Asia Tenggara yang saling peduli dan berbagi dalam membangun "an ASEAN community of caring societies" sendiri baru dilontarkan di Kuala Lumpur pada 15 Desember 1997 yang kemudian dikenal dengan “ASEAN Vision 2020” (Anwar, 2009:21). Pada prinsipnya dengan adanya ASEAN Charter, diharapkan akan terbentuk suatu kawasan Asia Tenggara yang lebih erat dan memiliki kekuatan dalam bidang ekonomi, sosial, politik dan pertahanan. Sedangkan secara internal diharapkan dengan adanya piagam ASEAN ini, kerja sama antar negara-negara di ASEAN akan lebih solid.

Hal tersebut juga dapat meningkatkan posisi tawar ASEAN yang lebih kuat dalam percaturan politik internasional, karena telah memiliki legal based. Piagam ASEAN (ASEAN Charter) bertujuan untuk mentransformasikan ASEAN dari sebuah asosiasi politik yang longgar menjadi organisasi internasional yang memiliki dasar hukum yang kuat (legal personality), dengan aturan yang jelas serta memiliki struktur organisasi yang efektif dan efisien. Hal ini tentunya menjadi babak baru bagi terciptanya kerja sama antar negara-negara anggota ASEAN di berbagai bidang baik politik, ekonomi, maupun sosial dan budaya. Sebagai negara yang memiliki peranan penting dalam berbagai kerjasama di kawasan ASEAN, Indonesia amat berkepentingan mewujudkan integrasi penuh ASEAN pada tahun 2015. Salah satu syarat bagi integrasi penuh ASEAN adalah kerjasama dan penetapan Piagam ASEAN yang telah ditandatangani oleh seluruh kepala negara ASEAN pada KTT ke-13 di Singapura pada Desember 2007. Penyusunan Piagam ASEAN sesungguhnya merupakan suatu kebutuhan dan konsekuensi dari telah dicapainya kesepakatan pembentukan Komunitas ASEAN pada tahun 2003 sebagaimana tertuang dalam Bali Concord II yang dihasilkan saat ASEAN di bawah 
kepemimpinan Indonesia. Kerjasama regional dengan negara-negara ASEAN adalah wujud nyata dari Mukadimah Undang Undang Dasar Negara Republik Indonesia Tahun 1945, yaitu politik luar negeri Indonesia yang bebas dan aktif.

Kerja sama yang dibangun tentunya harus memiliki tujuan bersama, berdasarkan kepentingan dan keuntungan bersama dengan asas saling menghormati dan mengakui kedaulatan, kesetaraan, integritas wilayah, dan pengakuan akan keberagaman di antara negaranegara ASEAN tanpa ada intervensi dari negara-negara maju. Dalam sistem internasional, negara merupakan unit, dengan kata lain negara tidak dapat lepas dari situasi yang mengandung permasalahan soal persaingan atau perebutan power. Adalah merupakan suatu kewajiban bagi negara bangsa dalam sistem internasional seperti ini untuk memberikan tanggapannya atas situasi dan berbagai tujuan nasional yang diinginkan oleh negara bangsa sesuai dengan kepentingan nasionalnya masing-masing. Negara-negara kawasan Asia Tenggara, merupakan lingkaran konsentris pertama kawasan terdekat Indonesia dan pilar utama pelaksanaan politik luar negeri. Kerja sama internasional adalah elemen penting dalam pelaksanaan kebijakan dan politik luar negeri Indonesia. Melalui berbagai kerja sama internasional, Indonesia dapat memanfaatkan peluang-peluang untuk menunjang pembangunan nasionalnya. Kerja sama regional, juga memegang peranan kunci dalam pelaksanaan kerjasama internasional Indonesia. Piagam ASEAN memiliki nilai yang sangat strategis bagi kepentingan nasional.

Kerja sama ASEAN yang telah berlangsung selama lebih dari empat dekade tersebut, dirasakan perlu diperkuat lagi guna menghadapi berbagai perubahan dan tantangan global. Upaya bersama untuk mempertahankan stabilitas keamanan perdamaian kawasan perlu diperkuat dengan tetap meningkatkan upaya bersama memajukan pertumbuhan ekonomi dan kesejahteraan rakyat. Hal ini memperlihatkan bahwa pembentukan Piagam ASEAN yang disusun berdasarkan tiga pilar yaitu komunitas politik dan keamanan, komunitas ekonomi dan komunitas sosial budaya, merupakan usaha dari negara-negara anggota ASEAN untuk meningkatkan kerjasama yang lebih terintegrasi serta menyeluruh demi kemajuan dan kemadirian kawasan Asia Tenggara.

Dalam penelitian ini, rumusan masalahnya (problem questions) adalah sebagai berikut. Apakah kepentingan Indonesia dalam meratifikasi Piagam ASEAN ? Maksud penelitian ini adalah mengetahui secara ilmiah (scientific curiosity) tentang kepentingan Indonesia dalam meratifikasi Piagam ASEAN. Selanjutnya mengungkap, mengenali, dan menganalisis tentang kepentingan Indonesia dalam meratifikasi Piagam ASEAN tersebut. Tujuan penelitian ini adalah untuk mempelajari dan menganalisis hal-hal yang melatarbelakangi pemerintah Indonesia 
meratifikasi Piagam ASEAN. Hasil penelitian ini diharapkan dapat berguna, baik bagi pengembangan ilmu (aspek teoritis) maupun guna laksana (aspek praktis), yaitu sebagai berikut.

Bagi Pengembangan Ilmu (Aspek Teoritis), hasil penelitian ini merupakan fakta tentang eksplanasi kepentingan Indonesia meratifikasi Piagam ASEAN, dalam rangka meningkatkan kerja sama ASEAN yang telah teruji secara empirik. Jika fakta ini dijalin dengan fakta lain secara bermakna (meaningfull construct), maka bisa merupakan teori tingkat tertentu dalam ilmu sosial (social sciences), khususnya Ilmu Hubungan Internasional.

Guna Laksana (aspek Praktis), hasil penelitian ini diharapkan juga berguna bagi Program Studi Hubungan Internasional Fakutas Ilmu Sosial dan Ilmu Politik Universitas Kristen Indonesia, berupa informasi dan masukan berharga terkait kepentingan Indonesia dalam meratifikasi Piagam ASEAN dalam upaya meningkatkan kerja sama ASEAN, sehingga tujuan terbentuknya ASEAN dapat segera diwujudkan.

\section{Kerangka Teori}

\section{Teori Organisasi Internasional}

Terkait bahasan teori organisasi internasional, Mandalangi (2000:24), mengemukakan sebagai berikut. "Organisasi internasional memiliki arti ganda, yakni dalam arti luas dan sempit. Organisasi dalam arti luas maksudnya adalah organisasi yang melintasi batas negara (internasional) baik bersifat publik maupun privat, sedangkan organisasi dalam arti sempit adalah organisasi internasional yang hanya bersifat publik".

Hal senada juga dikemukakan oleh Istanto (2002:20) sebagai berikut:

"Yang dimaksud dengan organisasi internasional dalam artian luas adalah bentuk kerja sama antar pihak yang bersifat internasional dan untuk tujuan yang bersifat internasional. Pihak-pihak yang bersifat internasional itu dapat berupa orang perorangan, badan-badan bukan negara dari berbagai negara, atau pemerintah negara. Menyangkut tujuan internasional adalah tujuan bersama yang menyangkut kepentingan berbagai negara”.

Secara sederhana, dari kedua definisi di atas, dapat dikemukakan bahwa organisasi internasional merupakan suatu organisasi yang baik gerak, maupun pelakunya melintasi batas sebuah negara, berangkat dari kesepakatan masing-masing anggota untuk bekerja sama, memiliki regulasi yang mengikat anggota, dan untuk mewujudkan tujuan internasional tanpa meleburkan tujuan nasional masing-masing anggota dari organisasi internasional yang bersangkutan. Perserikatan Bangsa-Bangsa (PBB) pada dasarnya merupakan sebuah organisasi yang bertujuan sama dengan Lembaga Bangsa-Bangsa (LBB). Namun, secara struktur 
organisasi, PBB bersifat lebih mengikat dan lebih memiliki peranan dalam dunia internasional sebagai sebuah organisasi atau lembaga internasional. Hal ini dipelajari dari kelemahan LBB sebelumnya.

Seiring dengan struktur organisasi yang jelas dan bersifat lebih mengikat terhadap negara-negara anggotanya, PBB dianggap sudah memiliki peran tersendiri dalam dunia internasional. Ini kemudian menjadi latar belakang sehingga organisasi internasional cukup terlihat dalam interaksi-interaksi internasional. Selain itu, organisasi internasional pun cukup memiliki peranan internasional. Sehingga, aktor internasional yang sebelumnya sangat didominasi oleh sistem negara mulai sedikit bergeser dengan menerima beberapa aktor lain dalam sebuah interaksi internasional seperti organisasi internasional, organisasi pemerintah dan atau non-pemerintah yang melintasi batas negara, perusahaan-perusahaan internasional, dan individu.

Dengan demikian, dalam mempelajari organisasi internasional didapatkan dua pendekatan umum yang berkaitan dengan teori organisasi internasional; pendekatan rezim dan pendekatan institusional. Seperti dijelaskan pada paper sebelumnya rezim merupakan seperangkat prinsip, norma, aturan dan pengambilan keputusan. Berikut institusi, lebih komplek daripada rezim, karena institusi memiliki struktur yang jelas. Barkin (2006:23) menganalogikan pendekatan rezim dan pendekatan institusional pada kasus institusi politik dan sering disebut sebagai pendekatan Black Box. Dikatakan sebagai Black Box karena dapat melihat misalnya output dari institusi politik tersebut, seperti kebijakan, aturan, denda dan sebagainya, di sisi lain tidak tahu apa yang terjadi di Black Box itu sendiri. Pendekatan rezim lebih cenderung dan fokus kepada input dan output yang ada, tidak mempertimbangkan adanya tekanan-tekanan sehingga pemerintah mengeluarkan kebijakan tersebut.

Analisis dari rezim termasuk dalam pendekatan black box, dan analisis dari pendekatan institusional berfokus pada apa yang terjadi di dalam Black Box (Barkin, 2006:27). Singkatnya, pendekatan rezim mempelajari apa yang terlihat dari luar, dan pendekatan institusional memfokuskan diri apa yang terjadi di dalam. Lebih lanjut, (Barkin, 2006:28) menjelaskan sebagai berikut.

“Analisis rezim menjadi yang paling dominan tahun 1980an, bahkan saat ini masih menjadi salah satu pendekatan dominan dalam mempelajari organisasi internasional. Perbedaan mendasar antara analisis rezim dan analisis institusional adalah pada aktor. Analisis rezim memandang negara adalah aktor utama dan merekalah sumber dari hasilhasil politik internasional. Analisis institusional melihat Organisasi Internasional sebagai aktor yang dapat melakukan sesuatu untuk mempengaruhi negara. Analisis rezim menyatakan bahwa organisasi internasional tidak bisa terbentuk tanpa campur tangan 
negara, dan jika suatu organisasi internasional dapat bekerja efektif tidak lain karena dukungan negara".

Banyak kajian awal dari organisasi internasional, pendekatan institusional memasukkan organisasi internasional ke dalam kategori analisis institusi formal. Institusi Formal memiliki struktur, organisasi, dan hirarki birokrasi yang formal. Hal awal yang wajib diperiksa oleh analisis ini adalah piagam organisasi, dan biasanya menyangkut perjanjian internasional. Piagam tersebut menjelaskan secara spesifik kapan dan mengapa organisasi internasional lahir, disebut apa organisasinya, siapa saja yang menjadi dan boleh menjadi anggota, proses pengambilan keputusan, struktur voting, hingga aturan pengeluaran anggota dari organisasi. Tidak jarang pula bagaimana mekanisme institusi itu bekerja juga dituangkan dalam piagam organisasi. Jadi, organisasi internasional dapat diibaratkan organisme. Ia dapat mati, tapi ia juga dapat tumbuh dan berkembang. Organisasi internasional dikatakan mati jika fungsinya usang atau bahkan diganti oleh organisme lain.

Di sisi lain, organisasi internasional dapat tumbuh dan memiliki peran baru. Contohnya European Coal and Steel Community (ECSC), yang digantikan oleh Uni Eropa. Pada keadaan seperti inilah, golongan neofungsional yang berdasarkan pendekatan rezim, menyatakan bahwa negara-negara sebagai input dapat membentuk kebijakan/perjanjian baru. Perjanjian baru ini dapat mengubah kebijakan pemerintah dari negara-negara tersebut. Golongan neofungsional mengakui perspektif institusional, salah satunya adalah pengakuan atas isu-isu yang berkembang di dalam organisasi, seperti faktor pemimpin politik. Golongan neoinstitusional membuka diri dengan tidak hanya berpaku pada keadaan internal organisasi, juga faktor dari luar yang dapat membuat dinamika di dalam organisasi.

Kesimpulannya, ada dua pendekatan umum yang dapat digunakan untuk mempelajari teori organisasi internasional, antara lain; pendekatan rezim dan pendekatan institusional. Secara singkat, pendekatan rezim melihat input dan output dari luar organisasi. Sedangkan pendekatan institusional melihat internal organisasi sebagai input yang dapat menghasilkan output. Terdapat pula pendekatan lain, yaitu neofungsional isme yang menjadi awal dari teori rezim. Neofungsionalisme tidak melihat hanya pada isu-isu yang ada di dalam organisasi internasional, tetapi juga agenda internasional organisasi internasional itu sendiri. Pendekatan lainnya adalah neoinstitusinalisme bahwa neoinstitusionalisme lebih melihat dinamika yang saat itu terjadi pada organisasi. Neoinstitusionalisme menyatakakan bahwa keputusan organisasi internasional tidak hanya cenderung pada keadaan internal, tetapi juga misi/agenda dari organisasi. Menurut penulis, dinamika di luar dan prinsip dan norma dari 
organisasi tidak dapat dipisahkan, jadi dari 4 pendekatan di atas penulis memilih neoinstitusionalime, sebagai yang paling ideal.

\section{Teori Kepentingan Nasional}

Terkait dengan teori kepentingan nasional tersebut, berikut dikemukakan bahwa untuk menilai keberhasilan politik luar negeri yang dijalankan suatu negara maka hal yang perlu dilakukan adalah menentukan alat pembanding yang tepat. Hal tersebut dapat dilakukan dengan menjabarkan unsur-unsur fundamentalnya yang akan dicapai serta instrumen yang dimiliki suatu negara untuk mencapainya. Soenarko, dkk (1996:12) mengemukakan sebagai berikut. "Tujuan nasional yang ingin dicapai suatu bangsa dapat terlihat dari kepentingan nasionalnya yang dirumuskan elit suatu negara, sedangkan instrumen untuk mencapai tujuan tersebut tergambar dari strategi diplomasi yang merupakan implementasi dari kebijakan politik luar negeri yang telah dirumuskan". Dengan mengkaitkan kedua elemen tersebut, maka kita dapat menilai sejauh mana keefektifan pelaksanaan politik luar negeri yang dijalankan suatu negara dalam kurun waktu tertentu. Dengan demikian, kebijakan politik luar negeri yang dijalankan suatu negara dapat dianggap berhasil jika memiliki suatu strategi diplomasi tertentu yang secara efektif dapat melindungi pencapaian kepentingan nasional negara tersebut.

Politik luar negeri Indonesia dapat dianalisa dengan menggunakan kedua elemen tersebut. Jika analisa difokuskan untuk melihat kontribusi pelaksanaan politik luar negeri Indonesia pada pencapaian kepentingan nasional, maka akan tampak bahwa secara general politik luar negeri yang dijalankan pemerintah memang sesuai dengan tujuan nasionalnya. Dalam sistem internasional, negara merupakan suatu unit, dengan kata lain negara tidak dapat lepas dari situasi yang mengandung permasalahan-permasalahan mengenai persaingan atau perebutan power. Merupakan suatu kewajiban bagi negara bangsa dalam sistem internasional seperti itu untuk memberikan tanggapannya atas situasi dan berbagai tujuan nasional yang diinginkan oleh negara bangsa sesuai dengan kepentingan nasionalnya masing-masing. Dalam kaitan ini, Mas'oed (1990:34) mengemukakan sebagai berikut.'Kepentingan nasional adalah konsep yang paling populer dalam analisis hubungan internasional baik untuk mendeskripsikan, menjelaskan, meramalkan maupun menganjurkan perilaku internasional. Konsep kepentingan nasional digunakan dalam analisa politik dan aksi politik”. Sebagai alat analisis, konsep ini digunakan untuk mendeskripsikan, menjelaskan, atau mengevaluasi sumber-sumber atau ketepatan kebijakan luar negeri suatu negara. 
Kepentingan nasional sebagai alat politis, konsep ini berfungsi sebagai alat pembenaran dan mengusulkan kebijakan. Kedua penggunaan tersebut mengacu pada apa yang terbaik untuk masyarakat suatu negara. Ke dua penggunaan tersebut juga cenderung membatasi arti yang dimaksudkan menjadi apa yang terbaik bagi suatu negara dalam urusan-urusan luar negeri. Politik luar negeri suatu negara terdiri atas dua elemen utama yaitu tujuan nasional yang akan dicapai dan instrumen yang dimilikinya untuk mencapai tujuan nasional tersebut. Setiap negara bangsa tidak bisa menghindar dari konsep nasional tersebut berkaitan erat dengan tujuan-tujuan nasional suatu negara. Artinya, dalam melaksanakan tujuan nasional suatu negara tidak terlepas dari kepentingan nasional negara tersebut karena kedua elemen itu sangat penting peranannya. Bakry (1999:21) mengemukakan sebagai berikut.

"Secara normatif, konsep kepentingan nasional berkaitan dengan kumpulan cita-cita suatu bangsa yang berusaha dicapai melalui hubungan dengan negara lain. Kumpulan cita-cita, karena di dalamnya tidak hanya berisi cita-cita untuk mengejar power semata, tetapi juga cita-cita yang lain. Secara destruktif, kepentingan nasional dianggap sebagai tujuan harus dicapai suatu bangsa secara tetap melalui kepemimpinan pemerintahan".

Selanjutnya, Holsti (1987:37) mengemukakan sebagai berikut."Mengidentifikasi kepentingan nasional ke dalam tiga klasifikasi yaitu a. core values atau sesuatu yang dianggap paling vital bagi negara dan menyangkut tentang eksistensi suatu negara; b. middle range objectives, biasanya menyangkut kebutuhan memperbaiki derajad perekonomian; dan c. long range goals, merupakan sesuatu yang bersifat ideal, misalnya keinginan mewujudkan perdamaian dan ketertiban dunia". Berdasarkan uraian di atas, kepentingan nasional merupakan konsep kunci dalam politik luar negeri karena berisi acuan atau orientasi kebijakan luar negeri suatu negara dalam rangka menentukan tindakan dalam upaya mencapai tujuan yang hendak dicapai sehingga kepentingan nasional juga menjadi hal yang melatarbelakangi setiap pola hubungan interaksi yang terjadi antar dua negara atau lebih.

\section{Teori Integrasi}

Terkait dengan bahasan tentang konsep integrasi tersebut, dikemukakan bahwa selain konsep kepentingan nasional juga mengaitkan permasalahan ini dengan teori integrasi. Integrasi menurut Duverger (1994:41) adalah sebagai berikut.”Dibangunnya interdependensi yang lebih rapat antara bagian-bagian organisme hidup atau antar anggota-anggota dalam masyarakat. Dengan demikian integrasi adalah proses mempersatukan masyarakat yang cenderung membuatnya menjadi suatu kata yang harmonis didasarkan pada tatanan yang oleh anggota-anggotanya dianggap sama harmonisnya". Proses integrasi disebabkan adanya kebersamaan sejarah, adanya ancaman keamanan dari luar yang dapat mengganggu keutuhan suatu wilayah, adanya 
kesepakatan pemimpin, homogenitas sosial budaya serta agama, dan adanya saling ketergantungan dalam bidang politik dan ekonomi. Frankel (1989:32) mengemukakan sebagai berikut. "Integrasi nasional pada dasarnya mencakup dua masalah pokok yaitu 1. bagaimana membuat rakyat tunduk dan patuh kepada tuntutan-tuntutan negara, yang mencakup perkara pengakuan rakyat terhadap hak-hak yang dimiliki negara; 2. Bagaimana meningkatkan konsensus normatif yang mengatur perilaku politik setiap anggota masyarakat, konsensus tersebut tumbuh dan berkembang di atas nilai-nilai dasar yang dimiliki bangsa secara keseluruhan".

Hal senada juga dikemukakan oleh Sjamsudin (1994:11) sebagai berikut.’Teori integrasi lazim dikonsepsikan sebagai suatu proses ketika kelompok sosial tertentu dalam masyarakat saling menjaga keseimbangan untuk mewujudkan kedekatan hubungan-hubungan sosial, ekonomi, dan politik. Kelompok-kelompok sosial tersebut bisa terwujud atas dasar agama dan kepercayaan, suku, ras, dan kelas. Istilah integrasi nasional merujuk pada perpaduan seluruh unsur dalam rangka melaksanakan kehidupan bangsa, meliputi sosial, budaya, ekonomi, maka pengertian integrasi nasional adalah menekankan pada persatuan persepsi dan perilaku di antara kelompok-kelompok dalam masyarakat”. Surbakti (1992:43) mengemukakan sebagai berikut. Integrasi politik dibagi menjadi lima jenis yaitu 1. Integrasi bangsa, yaitu suatu proses penyatuan berbagai kelompok sosial budaya dalam satu kesatuan wilayah dan dalam suatu identitas nasional. Integrasi nasional diartikan sebagai penggabungan unsur-unsur yang berbeda menjadi satu kesatuan yang utuh. Kelompok budaya tersebut saling dihubungkan lebih erat. Arah kecenderungan yang akan terjadi bersumber dari masyarakat kecil menjadi masyarakat besar. 2 . Integrasi wilayah, adalah suatu pembentukan kewenangan nasional pusat terhadap wilayah atau daerah politik yang lebih kecil, yang terdiri atas satu atau lebih kelompok budaya. Dalam integrasi wilayah diperlukan konsep wilayah yang jelas serta adanya aparat pemerintah dan sarana kekuasaan untuk menjaga dan mempertahankan kedaulatan wilayah dari penetrasi luar. 3. Integrasi nilai, adalah suatu persetujuan bersama mengenai tujuan-tujuan dan prinsip dasar politik dan prosedur-prosedur penyelesaian konflik dan permasalahan bersama lainnya. Dengan kata lain, integrasi nilai merupakan penciptaan suatu sistem nilai (identitas nasional) yang dipandang ideal baik dan adil dengan berbagai kelompok masyarakat. 4. Integrasi elit dengan khalayak, merupakan suatu proses perlembagaan pola hubungan kewenangan antara pemerintah dan rakyat. 5. Perilaku integratif, ialah kesediaan warga masyarakat untuk bekerja sama dalam suatu organisasi besar dan berperilaku sesuai dengan cara yang dapat membantu pencapaian tujuan organisasi. 
Berdasarkan uraian di atas, teori integrasi tersebut sangat relevan guna memahami maksud dan tujuan dari negara-negara anggota ASEAN. Perkembangan politik internasional yang terjadi saat ini, menumbuhkan kesadaran dari negara-negara anggota ASEAN untuk melakukan kerjasama secara kolektif dalam mendorong proses integrasi regional yang lebih luas baik di bidang politik, ekonomi maupun sosial budaya. Pada prinsipnya, dengan adanya ASEAN Charter, diharapkan akan terbentuk suatu kawasan Asia Tenggara yang lebih erat dan memiliki kekuatan dalam bidang ekonomi, sosial, politik dan pertahanan. Piagam ASEAN juga memiliki nilai yang sangat strategis bagi kepentingan nasional Indonesia mengingat negara-negara kawasan Asia Tenggara merupakan lingkaran konsentris pertama kawasan terdekat Indonesia demi menjaga keutuhan dan kedaulatan wilayah Negara Kesatuan Republik Indonesia.

\section{Metode Penelitian}

Dalam penelitian ini, tipe penelitian yang tepat digunakan untuk memperoleh data adalah metode deskriptif analitis, yaitu membuat suatu gambaran secara sistematis, faktual, dan akurat mengenai fakta-fakta, sifat-sifat serta hubungan antar fenomena yang diteliti. Sehingga mendapatkan gambaran yang menyeluruh tentang pentingnya pemerintah Indonesia meratifikasi Piagam ASEAN. Penelitian deskriptif analitis menurut Sumhudi (1988:45) bertujuan membentuk gambaran (deskripsi) tentang fenomena sosial dan kemudian dicari hubungan antar fenomena yang ada.

Rakhmat (2002:25) mengemukakan sebagai berikut. Penelitian deskriptif ditujukan untuk 1. Mengumpulkan informasi aktual secara rinci dan melukiskan gejala yang ada; 2. Mengidentifikasi masalah dan memeriksa kondisi dan praktik yang berlalu; 3. Membuat perbandingan atau evaluasi; dan 4. Menentukan apa yang dilakukan kelompok lain dalam menghadapi masalah yang sama dan belajar dari pengalaman untuk menetapkan rencana dan keputusan ke depan. Dalam penelitian ini, teknik pengumpulan data yang digunakan adalah studi kepustakaan yaitu data diperoleh dengan membaca literatur yang relevan seperti buku, bahan perkuliahan, artikel-artikel, serta hasil penelitian yang pernah dilakukan terkait dengan pokok bahasan penelitian.

Penelitian ini menggunakan analisis kualitatif, yaitu dengan cara menghubungkan faktorfaktor dan gejala-gejala yang berhubungan dengan penelitian, sehingga didapatkan hasil atau jawaban yang sesuai dengan tujuan yang ingin dicapai. Dengan analisis kualitatif diperoleh gambaran sistematis mengenai isi dokumen. Dokumen kualitatif maupun kuantitatif tersebut 
diteliti isinya, kemudian diklasifikasikan menurut kriteria atau pola tertentu, dianalisis dan atau dinilai (Surakhmad, 1990:13), (Xintian, Yu, 2009:45).

\section{Pembahasan}

Kebijakan umum Pemerintah Indonesia pada organisasi-organisasi internasional didasarkan pada Peraturan Presiden No. 7 Tahun 2005 tentang Rencana Pembangunan Jangka Menengah (RPJM) Tahun 2004-2009, Bab 8 tentang Pemantapan Politik Luar Negeri dan Peningkatan Kerjasama Internasional. Melalui penetapan RJPM, Pemerintah berusaha meningkatkan peranan Indonesia dalam hubungan internasional dan dalam menciptakan perdamaian dunia serta mendorong terciptanya tatanan dan kerjasama ekonomi regional dan internasional yang lebih baik dalam mendukung pembangunan nasional. Prioritas politik luar negeri Indonesia dalam 5 tahun ke depan dituangkan dalam 3 program utama yaitu program pemantapan politik luar negeri dan optimalisasi diplomasi Indonesia, program peningkatan kerjasama internasional yang bertujuan untuk memanfaatkan secara optimal berbagai potensi positif yang ada pada forumforum kerjasama internasional dan program penegasan komitmen terhadap perdamaian dunia.

Sesuai dengan Keppres No. 64 Tahun 1999, keanggotaan Indonesia pada organisasi internasional diamanatkan untuk memperoleh manfaat yang maksimal bagi kepentingan nasional, didasarkan pada peraturan perundangan yang berlaku dan memperhatikan efisiensi penggunaan anggaran dan kemampuan keuangan negara. Begitu pula dalam hubungannya dengan negara-negara ASEAN. Berikut adalah hasil analisisnya terkait dengan kepentingan Indonesia dalam komunitas politik dan keamanan ASEAN, kepentingan Indonesia dalam komunitas ekonomi ASEAN, dan kepentingan Indonesia dalam komunitas sosial budaya ASEAN. Menurut Rudy (2006:16), ASEAN adalah organisasi internasional Antar Pemerintah (Inter-Governmental Organization) atau sering disingkat IGO, dan ASEAN merupakan Organisasi Internasional Regional.

\section{Analisis Kepentingan Indonesia Dalam Komunitas Politik dan Keamanan ASEAN}

Dalam Ilmu Hubungan Internasional, ada beberapa definisi yang menjelaskan tentang organisasi internasional, di antaranya dikemukakan oleh Cheever dan Haviland (1999:17) sebagai berikut. "Any cooperative arrangement instituted among states, usually by a basic agreement, to perform some mutually advantageous functions implemented through periodic meetings and staff activities”. Dijelaskan bahwa pengaturan bentuk kerjasama internasional yang melembaga antara negara-negara, umumnya berlandaskan suatu persetujuan dasar, untuk melaksanakan fungsi-fungsi yang memberi manfaat timbal-balik yang diejawantahkan melalui 
pertemuan-pertemuan dan kegiatan-kegiatan staf secara berkala. Terkait dengan keamanan ASEAN, gagasan dasarnya pertama kali dikemukakan oleh Sukma (dalam Anwar, dkk, 2009:35) kepada Departemen Luar Negeri Indonesia, yaitu pada Pertemuan Tingkat Menteri ASEAN (ASEAN Ministerial Meeting /AMM) ke-36 di Phnom Penh, Cambodia (2003).

Anwar, dkk (2009:35) mengemukakan sebagai berikut. "Pemerintah Indonesia menegaskan bahwa pada dasarnya Masyarakat Keamanan ASEAN adalah suatu masyarakat yang secara khusus mengandalkan proses damai dalam menyelesaikan perselisihan yang mungkin terjadi di antara sesama Anggota ASEAN". Kerja sama politik yang dicanangkan Indonesia dalam Masyarakat Keamanan ASEAN tersebut, merupakan pengembangan suatu lingkungan yang adil, demokratis dan serasi (harmonious), penegakan hak-hak dan kewajiban asasi manusia. Dengan mengetengahkan demokrasi dan hak asasi manusia, Indonesia memperluas konsep keamanan dari keamanan pemerintahan (regime security) ke keamanan manusia (human security). Masyarakat keamanan ASEAN berpegang teguh pada prinsip-prinsip non-intervensi, pengambilan keputusan berdasarkan mufakat, ketahanan nasional dan regional, saling menghormati kedaulatan nasional, penghindaran penggunaan ancaman ataupun penggunaan kekuatan dan penyelesaian perbedaan maupun perselisihan secara damai.

Dalam kaitan ini peranan organisasi internasional dalam politik dunia menurut Pentland (dalam Little and Smith, 1991:242-243), yaitu: a. Sebagai instrumen dari kebijakan luar negeri negara-negara anggota, b. Untuk mengatur perilaku dan tindakan negara-negara anggota, c. Bertindak berdasar keputusannya sebagai aktor/lembaga yang mandiri. Konsep Masyarakat Keamanan ASEAN tersebut mengacu pada Piagam Perserikatan Bangsa-Bangsa dan prinsipprinsip hukum internasional. Melalui pilar Masyarakat Keamanan ASEAN, asosiasi regional ASEAN ini sekaligus mengembangkan kerjasama politik, memperkuat keamanannya melalui pembentukan dan pemberlakuan norma-norma dan pengembangannya, pencegahan merebaknya konflik, pengembangan cara-cara penyelesaian konflik dan pembangunan perdamaian pascakonflik (post-conflict peace building). Dalam konteks komunitas politik dan keamanan, negaranegara anggota ASEAN menginginkan terciptanya situasi keamanan yang kondusif di kawasan tanpa ada campur tangan negara-negara di luar kawasan. Hal tersebut tentunya sejalan dengan norma-norma dasar yang menjadi landasan bagi hubungan antar negara-negara anggota ASEAN yaitu menentang penggunaan kekerasan dan mengutamakan solusi damai, otonomi regional, tidak mencampuri urusan internal negara anggota lain, menentang pakta militer, dan mendukung kerjasama pertahanan bilateral. 
Dengan makin kuatnya desakan agar ada sikap tegas terhadap Myanmar, para Pemimpin ASEAN sepakat untuk lebih melihat hal tersebut sebagai bagian dari urusan dalam negeri Myanmar. Pernyataan bersama para pemimpin negara ASEAN yang dibacakan oleh Perdana Menteri Singapura Lee Hsien Loong pada KTT ASEAN ke-13 di Singapura (29 November 2007) mengemukakan sebagai berikut. "Kekisruhan politik dalam negeri Myanmar jangan sampai mengganggu integrasi dan keberadaan komunitas ASEAN. Tantangan pada implementasi Komunitas Keamanan ASEAN adalah bagaimana masalah-masalah domestik dapat dibicarakan di tingkat ASEAN. Misi Masyarakat Keamanan ASEAN adalah mengangkat kerjasama politik dan keamanan ke tingkat yang lebih tinggi, agar negara-negara ASEAN tetap memelihara perdamaian di antara sesama anggota ASEAN maupun dengan negara lain”. Dalam perkembangannya, ASEAN telah memperlihatkan peran penting dalam menjamin stabilitas keamanan di kawasan ASEAN. ASEAN telah menjadi modalitas regionalisme Indonesia, khususnya sebagai batu sudut (corner stone) dari politik luar negeri Indonesia.

Dari pertimbangan geo-politik dan geo-ekonomi, Indonesia menjadi jangkar (anchor) dari kerja sama kawasan ASEAN. ASEAN sangat penting untuk menciptakan ketahanan regional dalam menghadapi ancaman keamanan yang konprehensif, dengan cara memperkuat kerja sama regional untuk merealisasikan suatu masyarakat ASEAN yang politically cohesive, economically integrated and socially responsible. Dasar politik luar negeri RI berdasarkan UUD 1945 dan Ketetapan MPR Nomor IV/MPR/1999 tentang Garis-garis Besar Haluan Negara (GBHN), menegaskan bahwa arah politik Indonesia yang bebas aktif dan berorientasi pada kepentingan nasional, menitikberatkan pada solidaritas antar negara berkembang, mendukung perjuangan kemerdekaan bangsa, menolak penjajahan dalam segala bentuk, serta meningkatkan kemandirian bangsa dan kerja sama internasional bagi kesejahteraan rakyat.

Dengan demikian, secara politik dapat mendukung proses demokratisasi, memperkokoh persatuan dan kesatuan, mendukung terciptanya kohesi sosial, meningkatkan pemahaman dan toleransi terhadap perbedaan, mendorong terwujudnya tata pemerintahan yang baik, mendorong pernghormatan, perlindungan dan pemajuan HAM di Indonesia.

\section{Analisis Kepentingan Indonesia Dalam Komunitas Ekonomi ASEAN}

Menurut Istanto (2002:20) bahwa yang dimaksud dengan organisasi internasional dalam artian luas adalah sebagai berikut.

"Bentuk kerja sama antar pihak yang bersifat internasional dan untuk tujuan yang bersifat internasional. Pihak-pihak yang bersifat internasional itu dapat berupa orang 
perorangan, badan-badan bukan negara dari berbagai negara, atau pemerintah negara. Adapun yang menyangkut tujuan internasional adalah tujuan bersama yang menyangkut kepentingan berbagai negara."

Secara sederhana, dapat dirumuskan bahwa organisasi internasional merupakan suatu organisasi yang baik gerak, maupun pelakunya melintasi batas sebuah negara, berangkat dari kesepakatan masing-masing anggota untuk bekerja sama, memiliki regulasi yang mengikat anggota, dan untuk mewujudkan tujuan internasional tanpa meleburkan tujuan nasional dari masing-masing anggota dari organisasi internasional yang bersangkutan. Terkait dengan penelitian ini, bahwa dalam perkembangan dinamika politik dan kerja sama di kawasan ASEAN, hal tersebut tidak dapat dilepaskan dari pengaruh besar globalisasi khususnya globalisasi ekonomi. Globalisasi ekonomi ditandai dengan persaingan yang makin tajam serta mengarah menjadi perang dagang. Munculnya kekuatan-kekuatan ekonomi baru di Asia Pasifik seperti Cina dan India, menuntut negara-negara ASEAN untuk melakukan kerja sama yang lebih solid dan menyeluruh.

Kondisi hubungan internasional juga didominasi oleh kepentingan dan aktivitas ekonomi yang menganut sistem ekonomi pasar. Menurut Effendi (1997:26), hal tersebut mengakibatkan terjadinya hubungan yang tidak seimbang antara negara maju khususnya negara-negara industri dengan negara berkembang; bahwa negara-negara industri maju menikmati keuntungan dengan berusaha menguasai pasar. Konsep Komunitas Ekonomi ASEAN, merupakan ide Singapura dan Thailand yang dicetuskan pada KTT ke-8 tahun 2002 di Kamboja. Lahirnya gagasan tersebut didasarkan atas kesadaran akan kehadiran Cina yang sudah memberikan ancaman nyata secara ekonomi. Dengan penduduk 1,2 miliar jiwa dan PDB 800 miliar dollar AS, investor dunia lebih tertarik dengan Cina dibandingkan ASEAN yang masih terkotak-kotak.

Singapura dan Thailand melihat bahwa Cina hanya bisa dihadapi dengan menjadikan ASEAN sebagai kesatuan ekonomi yang diinginkan investor dunia. Atas dasar konsep Komunitas Perekonomian ASEAN, para pemimpin negara-negara ASEAN ingin menjadikan ASEAN sebagai kawasan dengan aliran perdagangan, jasa dan investasi, serta para pekerja terampil. Hal tersebut diwujudkan dengan kerja sama yang lebih erat serta terintegrasi, melalui kebijakan ekonomi makro, kebijakan keuangan dan harmonisasi sistem hukum. Ralf Emmers, seorang pengamat ASEAN dari Institute of Defence and Strategic Studies (Singapura) mengemukakan bahwa alasan utama mengapa Singapura mendesak komunitas perekonomian adalah karena Singapura menyadari perekonomian dan keamanan adalah terkait satu sama lain. Hal tersebut berarti bahwa memperkuat keamanan tanpa memperkuat perekonomian adalah siasia. 
Hal senada juga dikemukakan pengamat politik dari Thailand (Chulalongkorn University) (Wattanayakorn, 2009) sebagai berikut. "Kemiskinan ekonomi menjadi ladang subur bagi tumbuhnya penyakit sosial seperti terorisme. Kemiskinan juga berpotensi menciptakan gerakan separatis, fundamental dalam berbagai bentuk". Dalam tataran masyarakat di bidang ekonomi, ASEAN telah bersepakat untuk mengintegrasikan perekonomian regional melalui pembebasan arus barang, jasa dan investasi langsung (direct investment) di kawasan Asia Tenggara. Integrasi ekonomi regional ASEAN tersebut diperlukan untuk meningkatkan produksi, memperluas pasar serta menarik investasi yang dapat menstimulasi perekonomian, sehingga dapat menciptakan lapangan kerja serta pertumbuhan ekonomi di negara-negara kawasan ASEAN. Peningkatan ekonomi di kawasan ASEAN didasarkan atas kebutuhan untuk menjadikan kawasan Asia Tenggara sebagai landasan produksi yang menarik bagi perusahaan-perusahaan dalam dan luar negeri.

Dengan memaksimalkan komplementaritas di antara negara ASEAN tersebut, adalah guna mencapai skala ekonomi dan menjadi produsen yang efisien. ASEAN bertekad untuk menjadi landasan produksi tunggal yang berdaya tarik besar bagi arus masuk investasi asing langsung (Foreign Direct Invesment). Terkait hal tersebut, Anwar (2009:53) mengemukakan sebagai berikut. "Landasan produksi yang terintegrasi tentunya akan memberikan kesempatan yang lebih besar bagi pembagian kegiatan industri di ASEAN, sehingga menciptakan kesempatan bagi efisiensi industri yang lebih besar dan cost competitiveness dalam rangkaian pilihan produk dan jasa". Terkait dengan pasar bersama yang membuka aliran barang dan jasa, investasi dan tenaga ahli secara bebas di kawasan ASEAN. Para pemimpin ASEAN menyetujui untuk membuat suatu cetak biru bagi penciptaan blok perdagangan bebas yang serupa dengan Uni Eropa.

Cetak biru tersebut, menuntut ASEAN menjadi satu entitas perekonomian pada 2015 untuk ASEAN 6 (Indonesia, Brunai Darussalam, Malaysia, Filiphina, Thailand, dan Singapura), dan untuk negara seperti Myanmar, Vietnam, Kamboja, dan Laos adalah 2018. Terkait hal ini, Pangestu (2007:23) mengemukakan sebagai berikut. "Dari sisi produksi barang, Indonesia sudah siap, meski butuh waktu guna meningkatkan keunggulan di sektor jasa. Indonesia harus melihat ASEAN Economic Community dengan cara positif. Indonesia tidak bisa menunda, karena kegiatan produksi barang dan jasa harus dibuat lebih kompetitif'. Kebijakan politik luar negeri adalah suatu kebijakan, sikap, dan langkah pemerintah RI yang diambil dalam melakukan hubungan dengan negara-negara lain, organisasi internasional, dan subjek hukum internasional lainnya dalam rangka menghadapi masalah internasional guna mencapai tujuan pembangunan nasional. Dengan demikian, kepentingan Indonesia secara ekonomi dan keuangan meratifikasi piagam ASEAN adalah mendorong pertumbuhan dan stabilitas ekonomi yang 
berkelanjutan, meningkatkan daya saing, meningkatkan kemampuan ilmu pengetahuan dan teknologi, meningkatkan kapasitas nasional dalam upaya pencapaian pembangunan nasional, mendorong peningkatan produktivitas nasional, mendatangkan bantuan teknis, grant dan bantuan lain yang tidak mengikat.

\section{Analisis Kepentingan Indonesia Dalam Komunitas Sosial Budaya ASEAN}

Terkait fungsi dan peranan organisasi internasional dalam hubungan internasional, bahwa setiap organisasi internasional tentu memiliki peranan dan fungsinya masing-masing. Bannet (2000:34) mengemukakan sebagai berikut.

"As adjuncts of the state system, international organizations can and do play a number of significant roles. Their chief function is to provide the mean of cooperation among states in areas in which cooperation provides advantages for all or a large number of nations. In many cases they furnish not only a place where decisions to cooperate can be reached but also the administrative machinery for translating the decisions into action. Another function is to provide multiple channels of communication among governments so that areas of accommodation may be explored and easy access will be available when problem arise".

Dari penjelasan Bennet di atas, fungsi organisasi internasional dapat disimpulkan: a. Sebagai sarana kerja sama antar-negara dalam bidang-bidang dimana kerja sama tersebut dapat memberi manfaat atau keuntungan bagi sejumlah negara. b. Sebagai tempat atau wadah untuk menghasilkan keputusan bersama. c. Sebagai sarana atau mekanisme administratif dalam mengejawantahkan keputusan bersama menjadi tindakan nyata. d. Menyediakan berbagai saluran komunikasi antar-pemerintah sehingga penyelarasan lebih mudah tercapai. Terkait dengan kerja sama ASEAN bidang sosial budaya, bahwa komunitas Masyarakat Sosial Budaya ASEAN mendasari proses berkelanjutan kerja sama Asia Tenggara sebagaimana ditegaskan dalam ASEAN Vision 2020 yang dicanangkan pada tahun 1997 silam. Masyarakat sosial budaya tersebut menurut Yani (2008:6) menetapkan ASEAN sebagai suatu komunitas masyarakat yang saling peduli dan terikat dalam kemitraan. Dasar pemikiran komunitas tersebut telah dicanangkan dalam Deklarasi Bangkok 1967.

ASEAN Socio Cultural Community Blueprint, cetak biru tersebut merupakan bagian dari upaya to promote a people oriented ASEAN in which all sectors or society are encourged to participate in, and benefit from the process of ASEAN integration and community building (Pasal 1, ayat 13 Piagam ASEAN). Lebih lanjut, Yani (2008:7) mengemukakan sebagai berikut. "Dengan adanya komunitas sosial budaya ASEAN diharapkan akan terdapat peningkatan interaksi dengan Entities Associated with ASEAN; interaksi antar rakyat negara-negara anggota ASEAN melalui berbagai kerja sama dalam bidang sosial budaya”. Komunitas sosial budaya ASEAN 
dimaksudkan untuk membawa ASEAN lebih dekat dengan masyarakatnya, lebih melibatkan masyarakat negara-negara anggota dalam berbagai program kegiatan ASEAN, sehingga pada masa yang akan datang ASEAN bukan hanya didominasi lagi oleh kalangan pejabat pemerintah dan diplomat. Komunitas Sosial Budaya ASEAN bermaksud menciptakan masyarakat yang saling perhatian (Caring Society) di kawasan dengan komitmen lebih besar untuk memerangi kemiskinan, penyakit dan perlindungan. Dalam konteks perumusannya, Masyarakat Sosial Budaya ASEAN diarahkan sebagai penyanggga atas efek-efek samping dari integrasi ekonomi.

Agenda Masyarakat Sosial Budaya ASEAN difokuskan pada upaya pengentasan kemiskinan dan pembangunan manusia, karena terkait dengan keutuhan masyarakat ekonomi dan keamanan. Ketimpangan sosial mengancam pembangunan ekonomi dapat memperparah kemiskinan, pengangguran, kelaparan, dan penyakit. ASEAN mendorong kerja sama di bidang pembangunan sosial dan meningkatkan taraf kehidupan dari kelompok-kelompok disadvantaged dan penduduk desa, dan harus pula mengajak semua sektor masyarakat khususnya perempuan, generasi muda dan masyarakat lokal untuk berpartisipasi aktif dalam usaha ini. Terkait dengan masalah perempuan tersebut, Anwar (2008:60) mengemukakan sebagai berikut. "Deklarasi Cebu mendorong partisipasi sejajar dan efektif dari para wanita di semua bidang dalam proses pembangunan komunitas ASEAN". Pengembangan sumber daya manusia (SDM) merupakan strategi utama bagi penciptaan kesempatan kerja, pengentasan kemiskinan, dan penghapusan kesenjangan sosial ekonomi, serta menjamin pertumbuhan ekonomi secara merata.

ASEAN akan melanjutkan upaya-upaya yang dilakukannya untuk meningkatkan mobilitas di tingkat regional serta pengakuan mutual atas kemampuan profesional, tenaga-tenaga terlatih dan pengembangan keterampilan. Figur utama Masyarakat Sosial Budaya seperti tercantum dalam ASEAN Socio Cultural Community Plan of Action 2004 adalah 1. Akses merata ke berbagai peluang yang bersifat universal; 2. Potensi manusia akan dipupuk agar maksimal; 3. Normanorma sosial dan keadilan yang merata akan terus ditegakkan; 4. Lingkungan dan sumbersumber alam dilindungi dan dikelola untuk menunjang pembangunan yang berkelanjutan; 5 . Masyarakat madani akan diarahkan untuk memberikan masukan dalam pemilihan kebijakan; 6 . Rakyat sehat baik pikiran maupun jasmani dan hidup dalam keserasian dalam lingkungan yang aman,; dan 7. Warga ASEAN berinteraksi dalam ikatan sejarah yang sadar akan komunitasnya, menyadari warisan budaya dan terikat oleh identitas regional yang sama.

Atas uraian tersebut, menunjukkan bahwa nilai-nilai yang terpapar dalam ASEAN Socio Cultural Community Plan of Action 2004, adalah dilandasi oleh setiap pemikiran dan tindakan dalam pembangunan masyarakat sosial budaya ASEAN yang sejati, menitikberatkan 
pengembangan nilai-nilai kemanusiaan dan keterlibatan manusia ASEAN secara umum dalam menyumbangkan pikirannya bagi langkah-langkah kebijakan guna mengembangkan masyarakat ASEAN tersebut. Adanya Komunitas Sosial Budaya, bangsa-bangsa di kawasan Asia Tenggara dapat mengembangkan kerja sama yang lebih baik, serta memberikan keuntungan bagi bangsa Indonesia. Melalui ASEAN Socio Cultural Community diharapkan akan meningkatkan kesadaran dan penghormatan masyarakat di kawasan Asia Tenggara atas keanekaragaman budaya dan kearifan lokal warisan budaya Indonesia.

Dengan adanya Piagam ASEAN, akan terjadi peningkatan kerja sama di berbagai bidang sosial, yaitu pengelolaan lingkungan hidup, pendidikan, ilmu pengetahuan dan teknologi, kesehatan serta penanggulangan bencana alam. Keberhasilan ASEAN dalam melahirkan piagam bersama, tidak otomatis bermakna hubungan negara-negara ASEAN semakin solid. Tantangan terbesar justru berada di lingkungan internal ASEAN sendiri, yaitu bagaimana para negara anggota ASEAN dapat mengimplementasikan piagam tersebut menjadi sebuah kekuatan yang dapat membawa ASEAN sebagai sebuah organisasi regional yang mampu memberikan keuntungan, serta kemajuan bagi para anggotanya.

Terdapat beberapa keuntungan bagi Indonesia dalam meratifikasi Piagam ASEAN -- yang berlandaskan tiga pilar yaitu politik keamanan, sosial budaya, dan ekonomi -- yaitu 1. Terciptanya peningkatan kerja sama di berbagai bidang sosial antara lain pengelolaan lingkungan hidup, pendidikan, ilmu pengetahuan dan teknologi, pemuda, dan perempuan, kesehatan, serta penanganan bencana alam; 2. Terpusatnya kegiatan ASEAN dan pembentukan Perutusan Tetap Negara-negara Anggota ASEAN di Jakarta melalui peningkatan frekuensi pertemuan ASEAN yang diadakan di Jakarta; 3. Terciptanya kesadaran dan penghormatan masyarakat di kawasan akan keanekaragaman budaya, kearifan lokal, dan warisan Indonesia; 4. Terciptanya penguatan ekonomi Indonesia dalam berintegrasi ke ekonomi global dengan meningkatkan daya tarik ekonomi ASEAN melalui penciptaan pasar tunggal dan berbasis produksi; 5. Terciptanya kawasan yang lebih kondusif bagi Indonesia untuk mengkonsentrasikan sumber dayanya guna peningkatan pembangunan nasional; 6. Berkurangnya potensi ancaman dan kejahatan lintas negara, baik dalam bentuk tradisional maupun nontradisional, melalui kerja sama yang lebih intensif antar Negara Anggota ASEAN; dan 7. Lebih terjaminnya integritas wilayah dan kedaulatan Negara Kesatuan RI, terutama untuk menghindari penggunaan wilayah-wilayah Negara Anggota ASEAN untuk kegiatan yang dapat membahayakan Indonesia.

Dengan demikian, kepentingan Indonesia meratifikasi piagam ASEAN secara sosial budaya adalah menciptakan saling pengertian antar bangsa, meningkatkan derajat kesehatan, pendidikan, 
mendorong pelestarian budaya lokal dan nasional, mendorong upaya perlindungan dan hak-hak pekerja migran; menciptakan stabilitas nasional, regional dan internasional.

\section{Kesimpulan}

1. Kepentingan Indonesia dalam meratifikasi Piagam ASEAN, erat kaitannya dengan semakin berkembangnya hubungan antar bangsa-bangsa di dunia, yang membutuhkan penyesuaian-penyesuaian terhadap kebijakan politik luar negeri demi terjaminnya kepentingan nasional Indonesia yang dilandasi ketentuan serta dasar hukum yang kuat.

2. ASEAN sejak awal bercita-cita mewujudkan kawasan Asia Tenggara yang bersatu, damai, dan penuh kebersamaan. Pasca berdirinya ASEAN tahun 1967, hubungan internasional antara negara-negara di kawasan Asia Tenggara dengan negara-negara di luar kawasan masih diwarnai dengan suasana perang dingin. Oleh sebab itu, salah satu tujuan ASEAN adalah mencegah terulangnya kembali konfrontasi antar negara-negara di Asia Tenggara. Dengan demikian, lingkup kerja sama awal terbentuknya ASEAN adalah masih bersifat fungsional, yaitu di bidang ekonomi, sosial, ilmu pengetahuan dan teknologi. Perkembangan politik internasional kini menumbuhkan kesadaran negara Anggota ASEAN guna melakukan kerja sama kolektif dalam mendorong proses integrasi regional lebih luas baik di bidang ekonomi, politik maupun sosial budaya serta menghilangkan segala hambatan guna terciptanya integrasi dan stabilitas regional.

3. ASEAN Charter bertujuan untuk mentransformasikan ASEAN dari sebuah asosiasi politik yang longgar menjadi organisasi internasional yang berlandaskan hukum yang kuat (legal personality), dan ketentuan yang jelas, serta memiliki struktur organisasi yang efektif dan efisien. Dengan adanya piagam tersebut, diharapkan terbentuk kawasan Asia Tenggara yang lebih erat dan memiliki kekuatan dalam bidang ekonomi, sosial, budaya serta keamanan. Secara internal diharapkan dengan adanya Piagam ASEAN, kerja sama antar negara-negara di ASEAN semakin solid. 


\section{Daftar Pustaka}

\section{Buku}

Abcarian, Gilbert. 1987. Perbandingan Sistem Politik Indonesia, Yogyakarta: Gajah Mada University Press.

Bakry, Suyadi Umar. 1999. Pengantar Hubungan Internasional, Jakarta: Jayabaya University Press.

Bannet, Le Roy. 2000. International Organization. Jakarta:

Cheever, Daniel S. dan Haviland, Field, Jr. 1999. Organisasi Internasional, Jakarta:

Fortuna Anwar, Dewi, dkk. 2009. Masyarakat Asia Tenggara Menuju Komunitas ASEAN 2015. Jakarta: Pustaka Pelajar

Frankel, Josef. 1989. International Relation in a Changing World, London: Oxford University Press.

Holsti K. J. 1987. Politik Internasional: Kerangka Analisa, Jakarta: Pedoman Ilmu Jaya.

Istanto, Sugeng. 2002. Organisasi Internasional, Kerja Sama Antar Pihak. Jakarta:

Mas'oed, Mohtar. 1990. Ilmu Hubungan Internasional, Disiplin dan Metodologi, Jakarta: Pustaka LP3ES.

Mandalangi. 2000. Organisasi Internasional, Jakarta:

Rudy, May, Teuku. 2006. Administrasi dan Organisasi Internasional, Jakarta:

Rakhmat, Djalaludin, 2002. Metode Penelitian Komunikasi. Bandung: Penerbit Remaja Rosdakarya.

Surakhmad, Winarno. 1990. Pengantar Penelitian Ilmiah: Dasar, Metode, dan Teknik, Bandung: Tarsito.

Soenarko, Soesiswo, dkk. 1996. Perkembangan Studi Hubungan Internasional Dan Tantangan Masa Depan dalam Evaluasi Pelaksanaan Politik Luar Negeri Indonesia, Jakarta: Pustaka Jaya.

Samuel, Barkin. J. 2006. International Organization: Theories and Institutions. New York: Palgrave Macmillan

Xintian, Yu. 2009. Combining Research on Cultural Theory and International Relations. 


\section{Jurnal}

ASEAN Secretariat. 2008. ASEAN Charter fully Ratified, October 21, 2008

Direktorat Jenderal Kerja Sama ASEAN Departemen Luar Negeri Republik Indonesia. 2007. ASEAN Selayang Pandang, Cetakan ke-17, Jakarta.

Ikrar Nusa Bhakti. 1997. Reinterpretasi Politik Luar Negeri Republik Indonesia Dan Kemandirian Regional Asia Tenggara, Studia Politika 2, Redifinisi Politik Luar Negeri RI. PPW LIPI.

Sofian Effendi. 1997. Indonesia Dan Dinamika Internasional, Studia Politika 2, Redefinisi Politik Luar Negeri RI. PPW LIPI.

\section{Makalah}

Dewi Fortuna Anwar, 2000. Menggagas Politik Luar Negeri Indonesia Baru, Makalah Dalam Orasi Ilmiah Pengukuhan Sebagai Ahli Peneliti Utama, PPW LIPI.

Yanyan Mochamad Yani, 2008. Piagam ASEAN, ASEAN Socio-Cultural Community (ASCC) Blueprint dan Indonesia, Makalah dalam Seminar Nasional "Sosialisasi ASEAN SocioCultural Community (ASCC) Blueprint” Departemen Luar Negeri Republik Indonesia, Bandung. 